\title{
СТРУКТУРА ПРОФЕСІЙНИХ ДОМАГАНЬ МАЙБУТНЬОГО ФАХІВЦЯ
}

\author{
Коваль Д. В. \\ здобувач третього (освітньо-наукового) рівня вищої освіти, \\ Університет імені Альфреда Нобеля, м. Дніпро, Україна
}

У статті визначено суть поняття «професійні домагання особистості»; представлено компоненти означеного утворення та їх зміст; акиентовано увагу на зв'язку адекватності професійних домагань із самооцінкою особистості; наголочено на завданні закладу освіти - формуванні адекватних професійних домагань майбутніх paxiвuіiв.

Ключові слова: професійні домагання, майбутній фахівець, самооцінка, компоненти професійних домагань особистості.

The article defines the essence of the concept of «professional ambitions of the individual»; the components of the specified education and their content are presented; emphasis is placed on the connection between the adequacy of professional ambitions and self-esteem; emphasis is placed on the task of the educational institution - the formation of adequate professional ambitions of future professionals.

Key words: professional ambitions future specialist, self-esteem, components of professional ambitions of the individual

Проблема адекватності професійних домагань молоді, що виходить на ринок праці, стає все більш актуальною в аспекті соціального напруження, пов'язаного із критичною масою робочих місць на ринку праці. Численні аналітичні дані свідчать про те, що велика частка випускників закладів освіти переоцінює рівень власної готовності до роботи за фахом і відмовляється почати професійну кар'єру за спеціальністю з огляду на невисоку заробітну платню, яку роботодавець пропонує для посад фахівців-початківців. Не маючи бажання набувати додаткових компетенцій, визначених у вакансіях необхідними для виконання фахових завдань, молодь зосереджує увагу на тимчасових пропозиціях з працевлаштування, які оплачуються вище, але не пов'язані із набутим фахом. Така ситуація актуалізує проблему оновлення фахових колективів у різних галузях i, на нашу думку, може знайти вирішення через формування у майбутніх фахівців адекватних професійних домагань. 
У наших попередніх дослідженнях було представлено суть професійних домагань особистості як особливого виду життєвих домагань, що виявляються в здатності аналізувати власні потреби, пов'язані із реалізацією та актуалізацією у професії; умінні об'єктивно ставитись до результатів власної діяльності на основі їх зіставлення із результатами інших суб'єктів ринку праці; усвідомлення рівня реальної відповідності та власної ресурсності щодо вимог працедавця, а також рівня готовності до діяльності в умовах постійної зміни вимог до професійної компетентності фахівця конкретної галузі.

Виходячи із змісту поданого визначення, акцентуємо увагу на тому, що професійні домагання, як і загальні життєві домагання, передусім залежать від самооцінки особистості та рівні ії претензій на успіх у конкретній сфері життя. У такій своїй думці спираємось на позиції інших науковців. Так, Г. Меднікова розкрила співвідношення між самооцінкою та рівнем домагань особистості й довела, що їх взаємозв'язок варто розглядати як єдине ціле, динамічну систему взаємодії структурних компонентів механізму саморегуляції [2]. А. Срофеєв зауважує про рівень домагань як здатність індивіда: під час вибору цілі орієнтуватися на певний «рівень реальності» («мрії», «надії», реальних можливостей» тощо); в час прийняття рішення правильно співвіднести свої можливості з умовами і точно передбачити результат; суб'єктивно розвести різні рівні цілей (ідеальні, реальні, актуальні), яка визначає зрілість особистості. Реалістичність рівня домагань він пов'язує з вольовою поведінкою індивіда, що спрямована на зниження негативних переживань невизначеного майбутнього і бажанням чітко та усвідомлено співвіднести рівень власних досягнень (або ж рівень здібностей) 3 досягненнями інших [1].

Отже, основою професійних домагань є така оцінка своїх здібностей та можливостей (ресурсності), збереження якої стає для людини потребою. Розбіжність між домаганнями і реальними можливостями людини призводить до неадекватної самооцінки, наслідком чого, за думкою Ю. Назар, може стати емоційна неврівноваженість, підвищена тривожність, агресивність, що суттєво впливає на їі успішність у діяльності. особистість з реалістичним рівнем домагань вирізняється упевненістю в своїх силах, наполегливістю в досягненні мети, більшою продуктивністю, критичністю в оцінці професійних результатів [3]. 
Завданням освітніх закладів має стати формування у майбутніх фахівців адекватних професійних домагань задля їх успішній та швидкій реалізації у професії. Для процесу формування будь-якого утворення обов'язковим $\epsilon$ визначення його структури та змісту компонентів, внаслідок чого стає можливою орієнтація на вибір засобів впливу на особистість 3 метою формування кожного із них. Спираючись на визначення поняття «професійні домагання фахівця», у структурі означеного утворення виокремлюємо такі компоненти:

- Мотиваційно-цільовий - усвідомлення професійної мети (конкретність, особистісна значущість, здатність до корекції мети; спрямованість на успіх у досягненнях);

- Знаннєвий — знання про життєву та професійну перспективу, Я-концепцію особистості, роль самооцінки та домагань у самореалізації; професійну кар'єру, вимоги до фахівця за професією/посадою;

- Особистісно-технологічний (володіння техніками рефлексії, самоаналізу результатів діяльності, стратегічного та тактичного планування професійної кар'єри; активність у набутті додаткових компетенцій).

Формування кожного із означених компонентів дозволить, на нашу думку, досягти мети набуття майбутнім фахівцем рівня адекватності професійних домагань, що в свою чергу сприятиме ефективній професійній реалізації випускників на ринку праці.

\section{Список використаних джерел:}

1. Ерофеев А. К. Развитие методов исследования уровня притязаний: автореф. дис. ... канд. психол. Наук : спец. 19. 00. 07. Москва : Научно-исследовательский институт общей и педагогической психологи, 1983. - 23 с.

2. Меднікова Г. І. Самооцінка та рівень домагань особистості як динамічна система : дис. ... канд. психол. наук: спец. : 19. 00. 07. Харків : Харківський держ. педагогічний ун-т ім. Г. С. Сковороди, 2002. — 194 с.

3. Назар Ю. О. Психологічні підходи до концептуалізації феномена «професійна успішність» URL https://www.lvduvs.edu.ua/documents_pdf/ visnyky/nvsp/02_2012_1/12nyuofpu.pdf 